is determined that the specialist xx1 Art. should be a highly skilled person capable of autonomy, initiative of creative thinking, and solving problems in a non-standard way.

Keywords: vocal-artistic education, creative potential, professional training, professional activity, competence, self-realization.

DOI: https://doi.org/10.31392/NZ-npu-142.2019.17

УДК 378.091

Малежик П. М.

\title{
ПЕДАГОГІЧНІ АСПЕКТИ РОЗВИТКУ ІНТЕЛЕКТУАЛЬНИХ УМІНЬ МАЙБУТНІХ ФАХІВЦІВ 3 КОМП'ЮТЕРНИХ НАУК ПІД ЧАС ВИВЧЕННЯ ТЕХНІЧНИХ ДИСЦИПЛІН
}

У статті розглянуто та проаналізовано науково-педагогічні джерела, щзо розкривають сутнісні аспекти технічної складової професійної підготовки майбутніх фахівиів з інформаційних технологій до професійної діяльності. Визначено та обтрунтовано педагогічні умови, необхідні для забезпечення розвитку інтелектуальних умінь майбутніх IT-фахівиів під час навчання технічних дисциплін. На основі аналізу джерел $з$ питань розвитку інтелектуальних вмінь студентів визначено завдання дослідження їх структури. Вказано на важливість розвитку інтелектуальних умінь в студента, щуо є невід'ємною складовою процесу формування професійних компетентностей майбутнього фахівия.

Визначенно $і$ обтрунтувано педагогічні умови та вибір засобів, щзо забезпечують формування структури інтелектуальних умінь майбутніх фахівців IT-галузі. Основою інтелектуальних умінь є система інтелектуальних дій, що складаються з логічних мисленнєвих операиій (прийомів): аналіз, синтез, виділення головного, порівняння, узагальнення, систематизація, конкретизація, абстрагування, доведення, моделювання, прогнозування. Інтелектуальні вміння не даються від народження в готовому вигляді, вони є одночасно $i$ результатом, $і$ умовою розвитку, щзо здійснюється в прочесі навчання $i$ виховання, під час взаємодї з навколишнім середовищем.

Нарощування кожного інтелектуального уміння у процесі вивчення технічних дисииплін можна реалізувати шляхом урізноманітнення вправ, ситуативних завдань, проектів. Психологічні механізми інтелектуальної поведінки формуються, а структура інтелекту емпірично залежить від процесів його формування. Чинником, який визначає успіх людини в тій або іншій складній реальній діяльності, є не рівень розвитку тих або інших інтелектуальних механізмів, які виявляються при виконанні тестів інтелекту, а інтелектуальний потенціал, який обумовлює можливість формування нових механізмів.

Ключові слова: технічна підготовка, педагогічні умови, інтелектуальні уміння, структура інтелектуальних умінь, майбутній фахівець з комп'ютерних наук.

Серед пріоритетних напрямів державної політики України є розвиток інформаційного суспільства та широке впровадження інформаційних технологій в усі галузі життєдіяльності людини. В зв'язку з цим, виникає потреба у висококваліфікованих IT-фрахівцях, які здатні до засвоєння, генерування та практичної реалізації нових наукових ідей, розроблення та використання сучасних технічних пристроїв [1]. Отже, на сучасному етапі 
розвитку суспільства існує попит на творчі особистості, що здатні мислити самостійно, генерувати оригінальні ідеї, приймати нестандартні рішення.

Інтелект, інтелектуальний розвиток та інтелектуальні уміння особистості $\epsilon$ предметом досліджень 3 педагогіки та психології. Такі дослідження $\epsilon$ важливими, не втрачають актуальності і на сучасному етапі. Це пов'язано з тим, що, одним з визначальних чинників економічного розвитку сьогодні $\epsilon$ інтелектуальний продукт, а в умовах ринкових відносин значення практичного інтелекту особливо зростає. В сучасному суспільстві соціальний статус найбільшою мірою визначається освітою, престижною професією, а надалі професійними досягненнями.

Результати аналізу досліджень дають змогу стверджувати про необхідність постійного стимулювання інтелектуального розвитку майбутніх ITфахівців, задоволення їх потреб в актуальній, цілеспрямованій самостійній діяльності, формування в них моральних і психологічних якостей, які необхідні людині в умовах інформаційного суспільства [1].

Питанням розроблення методичних систем навчання технічних дисциплін майбутніх фахівців з комп'ютерних систем у ВНЗ присвячували свої дослідження Т. В.Бодненко [3], І. С. Войтович [4], Ю. С. Жарких [5], Л.Г. Мельник [8]. моделювання та побудова моделей систем навчання технічних дисциплін розглядалися в роботах І. В. Захарової та Н. М. Поліщук [6], Д. О. Корчевського [7]. Огляд та аналіз програм підготовки IT-спеціалістів на магістерському рівні, а також розробки та обґрунтування підготовки відповідних навчальних планів досліджувала 3. С. Сейдаметова [9]. Проблема створення цілісної науково обґрунтованої методичної системи фрундаментальної інформатичної підготовки фахівців у галузі інформаційних технологій у ВН3 вирішувалася в роботі С.О.Семерікова [10]. В цих дослідженнях відзначається, що становлення ІТ-індустрії здійснюється на основі інноваційної методології за використання комп'ютерів, операційних систем, програм, новітніх засобів зберігання і передачі даних, що забезпечує досягнення найвищої горизонтальної спеціалізації. Однак, вітчизняна система підготовки фахівців з комп'ютерних наук ще не повною мірою відповідає вимогам галузі. Студенти зазвичай засвоюють чималий обсяг технологічних знань, які швидко застарівають і стають малопридатними для формування необхідних практичних навичок, а в кваліфікаційних вимогах, які розробляються з акцентом на застарілі поняття і підходи, не відстежуються сучасні вимоги ІТ-індустрії.

Вивченню суті інтелекту людини приділялася чимала увага у фрілософії, психології, педагогіці. Наукові уявлення про інтелект складалися, фрормувалися і розвивалися впродовж тривалого історичного періоду. Проблемою інтелекту займалися як зарубіжні вчені (Х. Гарднер, Дж. Гілфорд, Р. Олпорт, Ж. Піаже, Е. Торндайк та ін.), так і вітчизняні (Ю. К. Бабанський, І. Д. Бех, В.І.Бондар, С. У. Гончаренко, Г. С. Костюк, І. Я. Лейнер, В. Ф. Паламарчук, Ю. С. Рамський, О. Я. Савченко, 3. І. Слєпкань, О. В. Хуторський та ін.).

Низка досліджень присвячувалися педагогічним умовам інтелектуального розвитку майбутніх вчителів математики, фрізики [1], розвитку інтелектуальних умінь при навчанні за умов фундаменталізації інформатичної освіти [2]. В своїх дослідженнях П. Барнс і Т. Брук визначили 12 інтелектуальних процесів, які необхідні кожному незалежно від фрахової спеціалізації та рівня розвитку: 
абстрагування, аналіз, класифрікація, складання рівняння, оцінювання, узагальнення, побудова висновків, складання послідовності, імітація, синтез, теоретичне міркування, переклад або трансформація думки. Таким чином, в основі інтелектуальних умінь лежить система дій, які складаються з логічних розумових операцій: аналізу, синтезу, узагальнення, абстрагування, порівняння, конкретизації, знаходження зв'язків та відношень. Саме ці уміння необхідні майбутньому фахівцю 3 інформаційних технологій для здійснення професійної діяльності. Тому в процесі навчання у ЗВО необхідно застосовувати таку систему завдань, яка б сприяла розвитку інтелектуальних умінь студентів, однак зміст завдань, послідовність їх розміщення, рівень складності мають відповідати типовій програмі.

Метою дослідження $€$ визначення і обґрунтування педагогічних умов та вибір засобів, що забезпечують формування структури інтелектуальних умінь майбутніх фрахівців IT-галузі.

Згідно з наказом Міністерства освіти і науки України від 6 листопада 2015 року № 1151 ("Про особливості запровадження переліку галузей знань і спеціальностей, за якими здійснюється підготовка здобувачів вищої освіти", затвердженого постановою Кабінету Міністрів України від 29 квітня 2015 року № 266) напрями "Інформатика", “Комп'ютерні науки” та “Програмна інженерія" об'єднано в спеціальність “Комп'ютерні науки та інформаційні технології”, що належать до галузі знань “Інформаційні технології. Спеціальність “Комп'ютерні науки та інформаційні технології" для підготовки бакалаврів і магістрів $\epsilon$ найбільш широко охопленою дисциплінами галузі IT, в тому числі і дисциплінами технічного спрямування.

У вітчизняній психології знаходить поширення концепція "необмеженого розвитку" (Б. Г. Ананьев, Л.І.Анциферова, І.С. Кон, К. К. Платонов та ін.), згідно з якою розвитком є еволюційно-інволюційний рух, який не припиняється до моменту припинення самого життя. Це дає змогу передбачити, що психічний розвиток продовжується протягом всього життя і його показниками є психічні новоутворення і особливості, специфічні для кожного вікового періоду (що знайшло віддзеркалення в багато чисельних періодизаціях дитячого розвитку), отже студентському віку, як соціально-психологічній віковій категорії, який характеризується інтенсивним розвитком всієї структури особистості, інтелектуальної системи зокрема, також властиві певні психічні новоутворення і психічні особливості.

Існує два загальні підходи до розуміння поняття "інтелекту": факторний (ієрархічні моделі інтелекту) та експериментально-психологічний (структура інтелекту - незалежні інтелектуальні здібності). У психолого-педагогічних наукових джерелах під терміном “інтелект" переважно розуміють здатність об'єкта до діяльності: навчання; мислення; спілкування; адаптації; сприйняття, опрацювання відомостей тощо.

Інтелект - найбільш важливий чинник успішності професійної діяльності, тому навчання різним професіям виявляється практично в рівній мірі залежним від інтелекту.

В умовах ринкових відносин значення практичного інтелекту особливо зростає. В сучасному суспільстві соціальний статус найбільшою мірою визначається освітою, престижною професією, а надалі - професійними 
досягненнями.

Визначальне значення у фрормуванні професійних компетентностей майбутніх IT-фрахівців має фрормування та розвиток інтелектуальних умінь особистості в процесі навчання фундаментальних дисциплін [2].

Інтелектуальні уміння - це здатність суб'єкта навчального процесу свідомо виконувати розумові дії (аналіз, синтез, порівняння, узагальнення, систематизація, абстрагування, конкретизація тощо). Основою інтелектуальних умінь є система інтелектуальних дій, що складаються з логічних мисленнєвих операцій (прийомів): аналіз, синтез, виділення головного, порівняння, узагальнення, систематизація, конкретизація, абстрагування, доведення, моделювання, прогнозування. Інтелектуальні вміння не даються від народження в готовому вигляді, вони $€$ одночасно і результатом, і умовою розвитку, що здійснюється в процесі навчання і виховання, під час взаємодії з навколишнім середовищем [4].

Результати психологічних досліджень свідчать [4], що найсприятливішим для формування та розвитку інтелектуальних умінь $€$ студентський вік. У розвитку особистості в цей період, крім звичайного росту інтелекту, відбуваються його структурні зміни. Організовуючи навчання в університеті, потрібно враховувати вік студентів і закономірності розвитку психічних процесів, а також враховувати психолого-педагогічні особливості навчальнопізнавальної діяльності студентів.

3 погляду структурно-динамічної теорії психологічні механізми інтелектуальної поведінки фрормуються, а емпірично структура інтелекту залежить від процесів його формування. Слід підкреслити, що чинником, який визначає успіх людини в тій або іншій складній реальній діяльності, $є$ не рівень розвитку тих або інших інтелектуальних механізмів, які виявляється при виконанні тестів інтелекту, а інтелектуальний потенціал, який обумовлює можливість формування нових механізмів [5, 6, с. 39].

Незаперечним $€$ факт, що ефективним засобом розвитку та фрормування інтелектуальних умінь студентів майбутніх фахівців з інформаційних технологій вважається навчання математики [7]. Вивчення математичних дисциплін спрямоване на фрормування у студентів інтелектуальних умінь проводити обґрунтовані, послідовні, несуперечливі міркування:

- підтверджувати чи спростовувати результати дослідження;

- висловлюватися чітко, стисло, переконливо;

- передбачати важливі наслідки діяльності чи бездіяльності тощо.

Математика належить до наук, які $\epsilon$ теоретичною основою для подальшого вивчення спеціальних технічних дисциплін майбутніми IT-фрахівцями, які будуть працювати в галузі інфрормаційних технологій та комп'ютерних наук.

Аналіз психолого-педагогічної літератури та власний досвід роботи уможливили здійснення систематизації та структурування інтелектуальних умінь майбутніх ІТ-фрахівців, які доцільно розвивати в процесі навчання предметів математичного та технічного циклів, на основі трьох етапів мислення:

- сприймання й осмислення відомостей (аналіз і синтез, виділення головного, порівняння, означення і пояснення поняття); 
- трансформація знань, умінь і навичок (узагальнення, класифікація, систематизація, конкретизація і абстрагування, доведення і спростування);

- набуття та реалізація творчих умінь (моделювання, прогнозування).

Вивчення математичних та спеціальних технічних дисциплін пов'язане 3 інтенсивною розумовою діяльністю, наслідком якої $€$ розвиток інтелектуальних умінь, формування особистісних і професійних якостей IT-фрахівця, які допоможуть йому самореалізуватися. Враховуючи значення математичних методів (моделювання, проектування, дослідження і планування) у IT-галузі, визначено базові інтелектуальні уміння, які доцільно розвивати у майбутніх фахівців інформаційних технологій та комп'ютерних наук у процесі навчання основних і спеціальних технічних дисциплін. Спочатку визначимо вимоги до математичної підготовки майбутніх IT-фрахівців для успішного формування інтелектуальних умінь в подальшому вивченні технічних дисциплін:

1. Опанування теоретичних основ лінійної алгебри, аналітичної геометрії, математичного аналізу, теорії ймовірностей, математичної статистики та дискретної математики, студенти мають здобути знання 3 математичних дисциплін в такому обсязі, який може зумовити чітке розуміння технічних і технологічних процесів, типових для IT-галузі, які визначають операції та $€$ основою творчих умінь студентів:

- порівнювати між собою різноманітні дані;

- абстрагуватися і виділяти головне;

- аналізувати і ставити нові питання або виділяти нові проблеми, тощо.

2. Оволодіння обчислювальними уміннями (на репродуктивному і творчому рівнях) диференціального й інтегрального числення та математичної статистики, що в майбутньому стануть необхідним апаратом для розв'язування фахово-спрямованих дослідницьких задач. Інтелектуальні уміння студентів формуються в результаті здійснення інтелектуальної діяльності (форми життєдіяльності людини, основою якої $€$ процес створення інтелектуального продукту та відтворення інтелектуального капіталу).

3 метою подальшого розвитку інтелектуальних умінь студентів майбутніх IT-фрахівців визначимо завдання, які слід реалізувати у процесі навчання технічних дисциплін:

- залучати студентів до індивідуальної навчально-пізнавальної діяльності під час виконання лабораторних дослідницьких робіт, кейсових завдань, індивідуальних, парних та колективних проектів з основних базових технічних дисциплін;

- розвивати професійні та творчі здібності майбутніх ІТ-фрахівців, формувати у них уміння: виділяти загальні риси в різноманітних явищах; комбінувати елементи; формулювати гіпотезу і перевіряти її в подальшому; застосовувати метод наукового моделювання; використовувати комп'ютерну техніку (чисельне і комп'ютерне моделювання); аналізувати наукову літературу з певної професійної проблеми; заходити розумний вихід із суперечливих, іноді і конфліктних ситуацій, що виникають у професійній діяльності.

Інтелектуальні уміння студентів формуються у результаті здійснення інтелектуальної діяльності - форми життєдіяльності людини, основою якої $€$ процес створення інтелектуального продукту та відтворення інтелектуального 
капіталу.

На основі аналізу теоретичних і практичних досліджень з проблеми інтелекту та його розвитку, нами визначено основні етапи розвитку інтелектуальних умінь:

- діагностика наявного рівня сформованості інтелектуальних умінь;

- мотивація необхідності розвитку уміння;

- рефлексія (розуміння суті і правила користування умінням);

- набуття досвіду використання умінь;

- застосування умінь до вирішення технічних завдань різних видів і рівнів складності, у тому числі і професійно спрямованих;

- узагальнення та перенесення набутих інтелектуальних умінь під час вивчення інших навчальних дисциплін, здійснення пізнавальної та фахової діяльності.

На процес навчання технічних дисциплін студентів впливає низка зовнішніх та внутрішніх обставин і умов здійснення навчально-виховного процесу в університеті, яких в тій чи іншій мірі необхідно дотримуватися під час підготовки фахівців ІТ-профрілю. У контексті нашого дослідження необхідно було вивчити та створити додаткові спеціальні умови організації педагогічного процесу, дотримання яких сприяло ефективному формуванню інтелектуальних умінь у студентів та отримання ними високих і якісних результатів під час опанування спеціальних технічних дисциплін.

Для визначення педагогічних умов ефективного розвитку інтелектуальних вмінь майбутніх IT-фрахівців у процесі навчання технічних дисциплін, нами були враховані існуючі методологічні підходи до організації навчання, дидактичні принципи та такими закономірностями навчання, як:

- обумовленість навчання суспільними потребами, взаємозалежність процесів навчання, освіти, виховання, розвитку особистості;

- принципи науковості, систематичності та послідовності;

- зв'язку навчання з життям тощо.

Обов'язковою, також, є необхідність урахування експертних оцінок. Отже, педагогічні умови можна сформулювати так:

1) нарощування у майбутніх IT-фрахівців інтелектуальних умінь, відповідно до складових їх структури, від сприймання й осмислення відомостей через трансформацію компетентностей до набуття та реалізації творчих умінь;

2) дотримання кожного з етапів формування інтелектуальних умінь від діагностики наявного рівня інтелектуальних умінь, через мотивацію, рефлексію і набуття досвіду у застосуванні інтелектуальних умінь до вирішення технічних завдань, і перенесення набутих інтелектуальних умінь на процес виконання іншої пізнавальної та фахової діяльності.

Відзначимо, що нарощування у студентів інтелектуальних умінь відповідно до складових їх структури здійснюється під час навчання. Вважаємо, що нарощування кожного інтелектуального уміння у процесі вивчення технічних дисциплін можна реалізувати шляхом урізноманітнення вправ, ситуативних завдань, проектів.

Поступове підвищення емоційної та творчої активності студентів для поетапного розвитку інтелектуальних умінь майбутніх IT-фрахівців у процесі вивчення технічних дисциплін, доцільно здійснювати через систему вправ і 
завдань, які складаються з 5 пакетів: підготовчі - пробні - тренувальні творчі - контрольні.

Під час виконання таких видів навчальних завдань, студенти закріплюють свої знання і вміння, проводять аналіз даних та отриманого результату, моделюють свою діяльність з виконання завдань, проектів, узагальнюють та систематизують навчальних матеріал, реалізують розроблені алгоритми, тощо. Доцільно і виважено дібраний зміст вправ і завдань, які пропонуються для вирішення під час вивчення фахово-орієнтованих технічних дисциплін, сприяє нарощуванню інтелектуальних умінь студентів.

Педагогічна умова дотримання кожного 3 етапів фоомування інтелектуальних умінь, стосується організації навчання технічних дисциплін, спрямованого на розвиток у майбутніх IT-фрахівців інтелектуальних умінь.

Діагностика рівня сформованості інтелектуальних умінь здійснюється під час вступного, підсумкового анкетування і тестування, а також після навчальних модулів. Мотивація необхідності розвитку інтелектуальних умінь формується через інтерес до вивчення технічних дисциплін, головним чинником якого $€$ демонстрація використання технічних знань у професійній діяльності IT-фрахівців, а також через впровадження системи нових завдань та проектної діяльності, тощо.

Взявши за основу виділені дидактичні цілі, наведемо структуру таких навчальних завдань з курсу “Операційні системи", використання яких спрямоване на формування технічних умінь:

- група завдань для формування загальних технічних умінь;

- група завдань для формування спеціальних технічних умінь;

- група завдань для формування конкретних технічних умінь.

Для побудови класифікації таких завдань при вивченні курсу “Операційні системи", використано склад технічних умінь 3-х видів: загальні, спеціальні, конкретні, які формуються за допомогою використання справ та методичних завдань типу: репродуктивні завдання; завдання орієнтувальної основи дій різного типу; завдання на аналіз конкретних ситуацій, завдання на моделювання конкретних ситуацій; завдання на виконання навчальних проектів (індивідуальних, в малих групах, колективних).

Розроблені методичні завдання, що містять структурованих опис ситуацій, запозичених із реальної практики, так звані ситуативні вправи, тексти яких називаються "кейсами". Конкретні приклади таких завдань та методичні особливості використання їх наведені в роботі [8].

Розроблені засоби складають систему різнорівневих завдань, основними критеріями яких $€$ поступове нарощування складності, варіативність, диференційованість. Система завдань будувалася за принципом ускладнення: поступовий перехід від завдань на фрормування умінь аналізувати та визначати головне, спостерігати, порівнювати, до узагальнення, систематизування, моделювання і на цій основі будувати завдання на формулювання проблем, висунення гіпотез, зіставлення отриманих результатів з передбаченими.

Осмислення суті і правила користування умінням сприяє свідомому виконанню навчальних завдань, попередженню помилок і міцному засвоєнню знань і вмінь. Усе це уможливлює ефективне формування вмінь, зокрема і інтелектуальних. Пропонуємо студентам здійснювати рефлексію не тільки після 
вирішення завдань чи вивчення теоретичного матеріалу, а і безпосередньо під час виконання того чи іншого завдання, щоб контролювати свою діяльність і уникати помилок. Набуття студентами досвіду застосування інтелектуальних умінь відбувається в процесі виконання значної кількості вправ та різноманітних задач і використанням інформаційно-комунікаційних та інтерактивних технологій. Для фрормування умінь порівнювати і систематизувати, моделювати і прогнозувати, доцільно використовувати програмні комплекси утиліт Sysinternals Марка Русиновича (Process Explorer).

Висновки. 3 метою формування інтелектуальних умінь викладачі кафедри застосовують проблемні ситуації, які моделюють елементи майбутньої професійної діяльності. Серед таких ситуацій окреме місце займають створювані під час семінарських та практичних занять ситуації успіху. Крім того використовуються імітаційно-ігрові моделі навчання, диференційовані завдання залежно від індивідуального рівня підготовки студента, тобто впроваджується особистісно орієнтований підхід у формуванні знань студентів.

3 погляду структурно-динамічної теорії, психологічні механізми інтелектуальної поведінки формуються, а структура інтелекту емпірично залежить від процесів його формування. Слід підкреслити, що чинником, який визначає успіх людини в тій або іншій складній реальній діяльності, $є$ не рівень розвитку тих або інших інтелектуальних механізмів, які виявляється при виконанні тестів інтелекту, а інтелектуальний потенціал, який обумовлює можливість формування нових механізмів.

\section{Використана література:}

1. Малежик П. М. Визначення структури готовності майбутніх IT-фахівців до професійної діяльності як педагогічна проблема. Наукові записки КДПУ. Серія: Педагогічні науки. Кропивницький, 2018. Вип. 173. С. 130-135.

2. Бодненко Т. В. Професійно-оріснтоване навчання технічних дисциплін майбутніх фахівців комп’ютерних систем : монографія. Черкаси : видавництво "ІнтерлігаТОР", 2016. 372 с.

3. Войтович I. C. Професійно орієнтована технічна підготовка майбугніх учителів інформатики : монографія. Київ : РВВ НПУ імені М. П. Драгоманова, 2013. 352 с.

4. Жарких Ю.С.Застосування комп’ютерних технологій у навчанні. Киӥвський національний університет імені Тараса Шевченка. Наукові записки. Т. IX : радіофізичний ф-т, військовий ін.-т. 2005. C. 42-47.

5. Захарова I. В., Поліщук Н. М. Формування моделі інформаційної галузі [Електронний ресурс]. URL : http//www. N buv.gov.ua / portal / soc - gum / vchu / N120p 019 - 024. Pdf. C. 20.

6. Корчевський Д. О. Інтеграція змісту професійної підготовки майбутніх фахівців з інформаційних технологій: теорія і практика : монографія. Київ : Педагогічна думка, 2016. 464 с.

7. Мельник Л. Г. На пороге информационного общества. Сумы : ИТд "Университетская книга", 2005. $430 \mathrm{c}$.

8. Сейдаметова 3. С. Методическая система уровневой подготовки будущих инженеров-программистов по специальности "Информатика" : дис. ... докт. пед. наук : 13.00.02. Київ, 2007. 559 с.

9. Семеріков С. О. Фундаменталізація навчання інформатичних дисциплін у вищій школі : монографія. Київ : НПУ імені М. П. Драгоманова, 2009. 340 с.

10. Національна рамка кваліфікацій [Електронний ресурc]. URL : http//zakon4.rada.gov.ua/laws/show/ 1341-2011-n\#n37

11. Лов'янова I. В. Дослідження рівнів сформованості інтелектуальних умінь старшокласників. Педагогіка вищої та середньої школи : збірник наукових праць, 2004. Вип. 7. С. 121-128.

12. Таренко Л. Б. Формирование интелектуальных умений студентов средствами информационнокоммуникационных технологий. Вестник ТИБСБИ. № 3. 2008.

13. Дружинин В. Н. Психология общих способностей. Санкт-Петербург : Питер, 1999. 368 с. 
14. Силенок Г. А. Здійснення інтелектуального розвитку студентів під час навчання математики майбутніх аграріїв. Педагогічні науки: теорія, історія, інноваиійні технології. 2014. № 5 (39). C. 397-405.

15. Малежик П. М., Малежик М. П. Особливості моделювання методичної системи технічної підготовки майбутніх спеціалістів з ІКТ. Наукові записки КдПУ. Серія: Проблеми методики фізико-математичної і технологічної освіти. 2017. Вип. 12. С. 121-127.

\section{References:}

[1] Malezhyk, P. M. (2018). Vyznachennia struktury hotovnosti maibutnikh IT-fakhivtsiv do profesiinoi diialnosti yak pedahohichna problema. Naukovi zapysky KDPU. Seriia: Pedahohichni nauky. K ropyvnytskyi, Vyp. 173, S. 130-135.

[2] Bodnenko, T.V. (2016). Profesiino-oriientovane navchannia tekhnichnykh dystsyplin maibutnikh fakhivtsiv kompiuternykh system : monohrafiia. Cherkasy : vydavnytstvo "InterlihaT OR", $372 \mathrm{~s}$.

[3] Voitovych, I.S. (2013). Profesiino oriientovana tekhnichna pidhotovka maibutnikh uchyteliv informatyky: monohrafiia. K yiv : RVV NPU imeni M. P. Drahomanova, $352 \mathrm{~s}$.

[4] Zharkykh, Y u. S. (2005). Zastosuvannia kompiuternykh tekhnolohii u navchanni. Kyivskyi natsionalnyi universytet imeni Tarasa Shevchenka. Naukovi zapysky. T. IX: radiofizychnyi f-t, viiskovyi in.-t. S. 42-47.

[5] Zakharova, I. V., Polishchuk, N. M. Formuvannia modeli informatsiinoi haluzi [Elektronnyi resurs]. URL : http//www. N buv.gov.ua / portal / soc - gum / vchu / N120p 019 - 024. Pdf. C.20.

[6] Korchevskyi, D. O. (2016). Intehratsiia zmistu profesiinoi pidhotovky maibutnikh fakhivtsiv z informatsiinykh tekhnolohii: teoriia i praktyka : monohrafiia. K yiv : Pedahohichna dumka, $464 \mathrm{~s}$.

[7] M elnik, L. G. (2005). Na poroge informacionnogo obshestva. Sumy : ITD “Universitetskaya kniga”, $430 \mathrm{~s}$.

[8] Sejdametova, Z. S. (2007). Metodicheskaya sistema urovnevoj podgotovki budushih inzhenerovprogrammistov po specialnosti "Informatika" : dis. ... dokt. ped. nauk: 13.00.02. Kiyiv, $559 \mathrm{~s}$.

[9] Semerikov, S. 0. (2009). F undamentalizatsi ia navchannia informatychnykh dystsypl in u vyshchii shkoli : monohrafiia. K yiv : NPU imeni M. P. Drahomanova, $340 \mathrm{~s}$.

[10] Natsionalna ramka kvalifikatsii [Elektronnyi resurs]. URL : http//zakon4.rada.gov.ua/laws/show/13412011-n\#n37

[11] Lovianova, I. V. (2004). Doslidzhennia rivniv sformovanosti intelektualnykh umin starshoklasnykiv. Pedahohika vyshchoi ta serednoi shkoly: zbirnyk naukovykh prats, Vyp. 7. S. 121-128.

[12] Tarenko, L. B. (2008). Formirovanie intelektualnyh umenij studentov sredstvami informacionnokommunikacionnyh tehnologij. Vestnik TIBSBI. № 3.

[13] Druzhinin, V. N. (1999). Psihologiya obshih sposobnostej. Sankt-Peterburg : Piter, 368 s.

[14] Sylenok, H. A . (2014). Zdiisnennia intelektual noho rozvytku studentiv pid chas navchannia matematyky maibutnikh ahrariiv. Pedahohichni nauky: teoriia, istoriia, innovatsiini tekhnol ohii, № 5 (39). S. 397-405.

[15] M alezhyk, P. M ., M alezhyk, M . P. (2017). Osoblyvosti modeliuvannia metodychnoi systemy tekhnichnoi pidhotovky maibutnikh spetsial istiv z IKT. Naukovi zapysky KDPU. Seriia: Problemy metodyky fizykomatematychnoi i tekhnolohichnoi osvity. Vyp. 12. S. 121-127.

МАЛЕЖИк П. М. Педагогические аспекты развития интеллектуальных умений будущих специалистов по компьютерным наукам при изучении технических дисциплін .

B статье рассмотрены и проанализированы научно-педагогические источники, раскрываюшие сущностные аспекты технической составляющей профессиональной подготовки будущих специалистов по информачионным технологиям в профессиональной деятельности. Определены и обоснованы педагогические условия, необходимые для обеспечения развития интеллектуальных умений будущих ИТ-специалистов во время обучения технических дисциплин. На основе анализа источников по вопросам развития интеллектуальных умений студентов определены задачи исследования их структуры. Показано важность развития интеллектуальных умений у студента, что является неотъемлемой составляющей проиесса формирования профессиональных компетенций будущего специалиста.

Определены и обоснованы педагогические условия и выбор средств, обеспечиваюших формирование структуры интеллектуальных умений будущих спещиалистов ИТ-отрасли. Основой интеллектуальных умений является система интеллектуальных действий, состоящих из логических мыслительных операџий (приемов): анализ, синтез, выделение главного, 
сравнение, обобщение, систематизация, конкретизаџия, абстрагирование, доказательство, моделирование, прогнозирование. Интеллектуальные умения не даются от рождения в готовом виде, они являются одновременно и результатом, и условием развития, что осуществляется в процессе обучения и воспитания, во время взаимодействия с окружающей средой.

Нарашивание каждого интеллектуального умения в процессе изучения технических дисииплин можно реализовать путем разнообразия упражнений, ситуативных задач, проектов. Психологические механизмы интеллектуального поведения формируются, а структура интеллекта эмпирически зависит от прочессов его формирования. Фактором, который определяет успех человека в той или иной сложной реальной деятельности, является не уровень развития тех или иных интеллектуальных механизмов, которые проявляются при выполнении тестов на интеллект, а интеллектуальный потенциал, который обусловливает возможность формирования новых механизмов.

Ключевые слова: техническая подготовка, педагогические условия, интеллектуальные способности, структура интеллектуальных умений, будущий специалист по компьютерным наукам.

MALEZHYK P. M. Pedagogical aspects of development of intellectual lessons of future faculty from computer sciences under the study of technical disciplines.

The article deals with and analyzes the scientific and pedagogical sources that reveal the essential aspects of the technical component of the professional training of future IT professionals for their professional activities. The pedagogical conditions necessary for the development of the intellectual skills of future IT specialists during the training of technical disciplines are determined and grounded. Based on the analysis of sources on the development of intellectual skills of students, the task of studying their structure is determined. It is shown on the importance of development of intellectual skills in the student, which is an integral part of the process of forming professional competences of the future specialist.

The pedagogical conditions and the choice of means that ensure the formation of the structure of intellectual skills of future IT industry specialists are defined and justified. The basis of intellectual skills is a system of intellectual actions consisting of logical thought operations (techniques): analysis, synthesis, allocation of the main, comparison, generalization, systematization, concretization, abstraction, proof, modeling, forecasting. Intellectual skills are not given ready-made from birth, they are both the result and the condition for development, which is carried out in the process of training and education, during interaction with the environment.

The development of each intellectual skill in the process of studying technical disciplines can be realized through a variety of exercises, situational tasks, and projects. The psychological mechanisms of intellectual behavior are formed, and the structure of intelligence empirically depends on the processes of its formation. The factor that determines the success of a person in one or another complex real activity is not the level of development of certain intellectual mechanisms that appear when performing intelligence tests, but the intellectual potential, which makes it possible to form new mechanisms.

Keywords: intellectual skills, pedagogical conditions, technical preparation, technical training, structure of intellectual skills, future specialist in computer science. 